\title{
Problems in Assessing the Expression of Illegal Work from the Aspects of Economic Activity and Policy in the EU
}

\author{
Rima Zitkiene, Zaneta Karazijiene, Egle Kazlauskiene
}

\author{
Mykolas Romeris University \\ Ateities st. 20, LT-08303, Vilnius, Lithuania \\ E-mail.rizit3@mruni.eu,zkarazijiene@mruni.eu,egle.kazlauskiene@mruni.eu \\ cross $^{\text {ref }}$ http://dx.doi.org/10.5755/j01.ee.27.1.8840
}

\begin{abstract}
Not only the size but also the composition of shadow economy and undeclared work are different in the EU Member States. The illegal work is apparent in sectors, where there is a high need of physical work, not requiring high qualification or competence, which is often associated with the second job that is performed in order to increase the income in an unofficial way, when the employers pay the whole or part of the salary illegally in order to avoid taxes; the employees work based on the contracts that are filled in an incorrect manner or without them, as well as when the overtime is not recorded, etc. The analysis of a scientific literature shows that the change and the situation in the market of the illegal work are assessed basing them on different methodological approaches, based on unequal criteria, the reformation of the labour market in different countries is implemented in different direction/uneven track. This is related not only with different economic and social status of the countries, demographical changes, legal basis, but also with different policy, views and assessment indicators. Objectives of the research: 1) considering the variety of theoretical concepts for illegal work, to specify the changes in the definition of illegal work in the individual EU countries; 2) to identify the assessment methodologies of illegal work and changes of its extent; 3) to review the extents of illegal work in the EU countries and Lithuania, by providing measures for reducing it.
\end{abstract}

Keywords: Illegal Work, Shadow Economy, Policy, Forms of Illegal Work, Features of Illegal Work, Methodology for Assessment of the Illegal Work.

\section{Introduction}

Currently, undeclared work is understood in a different manner. Due to the complexity of this matter which arise from different motives and strategies of companies, employees and employers, there is no uniform logic of the development of undeclared work (Pfau-Effinger, 2009). Various issues in defining the illegal work and the assessment of the illegal work as well as methodological issues were examined by such foreign scientis as: Fr. Jorg Alt, 1999; Pedersen, 2003; Diamantopoulou, 2002; Jonsson, 2002; Meldolesi, 2003; Schneider, 2001, 2012, 2014; Di Porto, 2009; Jorg A. SJ, 1999; Hazans, 2011; Henley et al., 2006; Perry et al., 2007; Kriechel, 2012; Maedhbh \& Comm, 2013; Brodolini, 2009; Feld \& Larsen, 2005; Cichocki \& Tyrowicz 2010, Pasternak-Malicka 2013, Dekker et al., 2010. Various aspects of illegal work were also examined by these Lithuanian scientists: Misiunas, 1999; Krumplyte, 2009; Krumplyte \& Samulevicius, 2010; Berzinskiene \& Juozaitiene, 2011; Zukauskas, 2014; Pocius \& Okuneviciute-Neverdauskiene, 2007; Martinkus et al., 2006; Dagiliene, Leitoniene \& Grencikova, 2014; Startiene \& Trimonis, 2009.

The problems of illegal work are widely examined in the scientific research of various countries and international organisations, and they are clearly defined by the laws of individual countries. The variety of definitions is noticed in scientific publications, practical studies, reports from various EU institutions and global organisations, namely illegal, otherwise, informal employment (Pedersen, 2003), shadow employment (Diamantopoulou, 2002), undeclared work (Jonsson, 2002), underground employment (Meldolesi, 2003; Schneider, 2001), while the all mentioned above divides the shadow economy into the legal and illegal activity (2012), unofficial employment in the labour market (Misiunas, 1999), the shadow of the labour market (Zukauskas, 2014), hidden labour market, moonlighting (Vos, Breesch \& Scheerder, 2012), nonstructured, nonofficial, nonorganized, anormal, submerged, nonvisible, atypical (Williams, 2009).

Even though the scientific studies do not provide a unified opinion on whether these terms mean the same up till this day, in general, it means that there are no written agreements between the employee and the employers, the taxes and the social insurance are not paid, work safety and compensation for the injuries experienced during the working hours are not guaranteed. Furthermore, the black/shadow labour market may include both the persons who are registered in the Labour Exchange and the persons who are not registered there. In other words, there may be a situation when a person is an officially registered unemployed person, receiving an unemployment allowance, who is at the same time employed in the black/shadow labour market.

According to Schneider (2012), the shadow economy covers the economic activities and income, which are received illegally, without meeting the state regulations and taxes. Undeclared work and shadow economy go 
along. Both factors are based on cheating and avoid paying legally due social contributions. Undeclared work always presents important tendencies in the economic system. Thus, it is of specific interest of policy makers to analyse the factors influencing of undeclared work (Arezzo, 2014). Misiunas (1999) states that the primary and at the same time the main assessment of the black economy is based on calculating unofficial employment in the labour market. In every country, the state institutions are not able to cover and know the processes of the labour market fully, which is also typical for Lithuania.

When summing up the factors and reasons of the shadow economy, Krumplyte (2009) also defines limitation of the legal work relations. A huge part of shadow economy consists of undeclared work, when the work is paid for illegally and the taxes as well as the income are prevented. According to the European Economic and Social Committee it is important to fight with the shadow economy and undeclared work for all of the Member States and to be united by adding to and connecting to the work everything that has been done in this field and was undertaken by the European Commission, the European Foundation for the Improvement of Living and Working Conditions (EUROFOUND) and other international organisations.

The analysis of the scientific literature shows that the changes and the situation in the labour market (as well as in the illegal market) are assessed basing them on different methodological approaches, based on unequal criteria; therefore, the reformation of the labour market in different countries is implemented in different directions/uneven track. This is related not only with different economic and social status of the countries, demographical changes, legal base, but also with different policy, views and assessment indicators. In this sense there is a relevant scientific problem considering in what theoretical concepts and methodological approaches the definition and expression of illegal work is expressed and based in the EU countries.

The object of the research is illegal work. The aim of the research is to identify and highlight the problems/differences in the assessment of the expression of illegal work from the aspect of economic activity and policy in the EU. In order to reach this goal the following objectives are formulated and solved for the research: 1) considering the variety of theoretical concepts for illegal work, to specify the changes in the definition of illegal work in the individual EU countries; 2) to identify the assessment methodologies of illegal work and the changes of its extent; 3) to review the extent of illegal work in the EU countries and Lithuania, by providing measures for reducing it.

Research methods of scientific literature analysis, the analysis of secondary data, comparative analysis, summary/ summation have been used.

\section{When Searching for the Limits of the Concept and Definition of the Illegal Work}

The modern global economic environment that is rapidly changing has a huge impact on the changes in the labour market structure both on the national and the EU country level. In a modern market economy the simple act of buying a service seems appealing — choosing and paying without further obligations. However, services are quite expensive as work is subject to high taxes. For manifold reasons many people instead opt to barter or help each other. It can be a habit, a way to be friendly, to build and maintain relations, a political standpoint - and because it is cheaper than buying. Acknowledged as wrong but in many instances acceptable, these exchanges highlight the inadequacies of the formal economy (Larsen, 2013). The indicators of the labour market reflect the economic status of a country and reveal its weak spots. Companies of the economic recession, seeking to stay in the market and to be able to compete had to optimise their activity, by at the same time intensively reducing the number of working persons (Berzinskiene \& Juozaitiene, 2011; VarelaLlamas, 2014). On the other hand, economy development tendencies in various EU countries show that as one of the most harmful and long-term economic fluctuations / cyclicality / effects of the crisis could be named as the increase in the illegal work.

The concept of undeclared work covers a variety of employment types, based on different motives of both employers and employees (Vos, Breesch \& Scheerder, 2012). Illegal work is not only a work without paying certain taxes, but also the one contracting the working laws as well as related with the territory in which it a person resides without a permission and it is paid for the performed activities. Such activity may also be performed by illegal immigrants, as stated by Jorg A. SJ, 1999 - who in other words are called by the author as labour migrants. Different concepts are used in order to define illegal work, such as "black work", "undeclared work", "unofficial employment", "unofficial work", "hidden unemployment", "shadow unemployment", "labour market shadow" and many other essential concepts, which describe the limits of the components/ expression and scope of the illegal work.

Zukauskas (2014) indicates that labour market shadow is a part of the shadow economy related to the work relations, where the hired work: is not legalised with a working agreement or in other form (e.g. business certificate); all or part of the salary is paid illegally. Pocius \& Okuneviciute-Neverdauskiene (2007) think that in Lithuania as in other post-communist countries, a complex structure of a specific labour market has formed. Aside from the main labour market segments, official employment and registered unemployment, which are particularly significant in the Western Europe countries, economy of our country has formed another two - hidden unemployment and unofficial employment. Martinkus et al. (2006) think that illegal work often does not require a full working day and lower qualification than the one that a person has is sufficient as well as such work is defined as hidden unemployment. Furthermore, a big number of persons only declare that they are searching for a job, but this is only a hidden lie, seeking to receive unemployment or welfare benefits. These benefits are received only in such case if a person has been registered in the Lithuanian Labour Exchange and comes to the Lithuanian Labour Exchange at the set time, while at other times he usually works illegally. Based on Martinkus et al. (2006), such unemployment shall be called shadow unemployment.

Illegal work is related with the shadow economy (Schneider, 2014); therefore, in some of the EU countries, 
when analysing the shadow economy a concept of undeclared work is used. Undeclared work is a common challenge for all of the European Union countries, which makes an unequal impact in different countries and economies. Such unequal impact should be taken into consideration, when forming the policy of the fight with the illegal work (SOC/480, 2013).

Undeclared work is any paid activity, which is legal in its nature, but is undeclared for the state institutions, considering the differences of legal systems in the Member States. This concept covers various activities: from the unofficial services of household maintenance up to hidden work of illegal residents, except for criminal activity (Williams, 2011). The very same definition is applied by OECD. Meanwhile the World Bank offers to include into the definition the employees that are hired without a contract and persons who work independently and do not take up professional activity, hiring no more than five employees (COM 628, 2007).

Effects of undeclared work may be classified based on various features - that are of origin, duration, and nature of work. Di Porto (2009) offers classifying the illegal work into:

1) regular illegal work (avoiding to pay taxes);

2) leisure-irregular illegal work (including the ones working independently, students, housewives and pensioners);

3) short-term-irregular illegal work (work of illegal immigrants);

4) multiple work (when legal work is undertaken and it is also worked additionally in the same company).

Krumplyte \& Samulevicius (2010) indicate that scientific literature usually makes a distinction between the full and the part-time types of undeclared work. "Informal employment" is described as employment of individuals without of a labour contract in order to avoid income taxes and social insurance contributions. "Part time" informal employment is defined as elimination of a portion of income in order to reduce payable taxes and social insurance contributions.

In the EU countries, the limits of the definition of the undeclared work are assessed/ interpreted differently, considering the economic situation of a country, political decisions, and social provisions; however, some general tendencies and features may be defined:

Both the employees and the employers participating in the process of the undeclared work are willing to take up the risk for additional income.

Usually, the extents of the undeclared work are influenced by the economic growth. The slower it is, the higher is the unemployment level and at the final result it influences the higher level of undeclared work.

Analysis of a scientific literature allows defining several essential features of the undeclared work:

- employers pay all or part of the salary for work avoiding the taxes;

- the employees work based on the contracts that are filled in an incorrect manner or without them;

- overtime is not recorded.

The undeclared work is usually apparent in sectors, where there is a high need of physical work, not requiring high qualification or competence: construction, agriculture, transport, trade sectors, household services, and nursing. This phenomenon is particularly persistent in small microlevel, such as the family business (Williams, 2010). Persons who work independently usually consciously choose the form of illegal work, because of the lack of competencies, experience and qualification skills they are not able to compete in the labour market. There is also a possibility of a socially oriented undeclared work, when the products and services are provided for such final users, who are relatives, friends, acquaintances, neighbours etc. (Egerton \& Mullan, 2008) Therefore the effect of illegal work shall be analysed not only in political and economic, but also in the social context.

In his study "Informal Workers across Europe" Hazans (2011) provides a concept of informal employment and researched thirty European countries, paying attention to the employees, working without contract as well as analysed the integration of informal work in Europe. He agrees with the opinion of Henley et al. (2006) stating that informality is based on temporary occupation/employment and the size of the employee's company mostly affects the choice of such practice.

Perry et al. (2007) claims that the big companies can also have a big amount of employees and not pay the social insurance contributions. A term formally self-employed is also emphasized when one works and the taxes are paid legally, but here is also informal self-employment, when one works without contracts, especially as family workers. Furthermore, Misiunas, (1999) indicates that the development of an unofficial labour market has a positive aspect - more and more people are independently solving their own employment problems, but there is a lot of negative consequences of the existence of the unofficial labour market: the ones who are working unofficially are totally socially unsecured and depending on the employers, the amount collected for the social insurance and income tax are reducing, at the same time with the possibilities for the country to at least minimally provide for socially supported population.

When analysing the experience of the individual countries a variety of measures for treatment of illegal work and political-economical measures were established. This depends on the fact of what institutions of the country are assigned the control of illegal work. The impact/research on these issues of Raisanen, Alatalo, Henriksen, Israelsson, Klinger (2012) shall be noted/ emphasised in the study about the labour market reformations, including illegal work in Denmark, Germany, Sweden and Finland.

The concept/definition of illegal work in Germany is identified in two aspects:

- as an undeclared work, which is legal, but is not declared for the institutions of the country;

- as well as illegal work of migrants. Illegal work of migrants is identified in two aspects: emigrants who are refugees and work emigrants (Kriechel, 2012).

The undeclared work in Ireland is defined as all the economic activity and economic units, which are not included in the official records or are recorded only in part. It is a complex phenomenon, covering employees and 
sectors of various types. The Irish Business and Employers Confederation enumerated undeclared work as one of the most essential phenomenon making negative effect to the Irish economy and business environment (Maedhbh \& Comm, 2013). The Irish Government notes that a lot of cash income is circulating in illegal work. Considering this there are much more transactions of cash in Ireland than the electronic transactions and the Central Bank of Ireland initiated a discussion on installing the electronic operation infrastructure. Electronic payment system would contribute to the clarity and monitoring of the operations (Maedhbh \& Comm, 2013).

Sweden and Finland use the concepts undeclared work. Institutions controlling illegal work in Sweden and Finland define it as any activity for which one is paid, which is not legal based on its nature, but is not declared to the state institutions, considering the differences of the legal systems in the countries. This means that the only difference between a declared and undeclared work is the fact that undeclared work is not announced to the tax, social security and work law institutions. All the other activity, which is understood as "shadow", cannot be defined as undeclared work. If such activity includes criminal features (e.g. drug dealing) it is already called criminal activity and if the services are provided, for which it is not paid, then it is "unpaid work"(Eurofound, 2013).

Categories of undeclared work are the same as in Germany. Only the benefit is emphasised a little more (see Table 1).

Receivers of the benefits from undeclared work in Finland and Sweden

\begin{tabular}{|l|l|l|}
\hline $\begin{array}{l}\text { Black work (hidden } \\
\text { income from work) }\end{array}$ & $\begin{array}{l}\text { Transaction without a record in the } \\
\text { accounting books. Usually they are } \\
\text { "cash without a check" }\end{array}$ & Legally this is attributable to the line of consumption in the books \\
\hline Benefit for an employee & $\begin{array}{l}\text { Undeclared income received in money or } \\
\text { other goods }\end{array}$ & $\begin{array}{l}\text { The employer pays the employee for the products/services, travel, rent of } \\
\text { equipment service, which is not established as a salary }\end{array}$ \\
\hline \multirow{3}{*}{ Benefit of the employer } & Undeclared salary for work & $\begin{array}{l}\text { Business burdened with additional expenses, reducing the profit tax that } \\
\text { needs to be paid }\end{array}$ \\
\cline { 2 - 3 } & Undeclared selling of the goods & $\begin{array}{l}\text { Receiving the goods/services and travels, using the employee or the } \\
\text { equipment for their needs does not increase the company's revenues }\end{array}$ \\
\hline
\end{tabular}

Based on the data of Central Statistical Office of Poland Unregistered employment in Poland in 2010, (in Polish Praca nierejestrowana w Polsce w 2010 r.), around $55 \%$ of people employed illegally have a regular job, and $45 \%$ - additional one (20 p.). For more than fifteen years the reasons of "black work" (in Polish. praca naczarno), which is also called "grey area" (in Polish szarej strefie) are examined in the labour market of the country.

Scientists in Poland use the concepts: illegal work (in Polish, praca nielegalna), unregistered work (in Polish, praca nierejestrowana) Pasternak-Malicka (2013), Cichocki \& Tyrowicz (2010). Labour Inspectorate of Poland and other state institutions of the country controlling work risk analyse illegal employment (in Polish, nielegalne zatrudniene). Furthermore, the concept of unregistered work in Poland can be considered as a synonym of the illegal work. The concept of illegal work was specified in 2004 and 2013 and based on the Polish "Work Marker News" it currently includes:

- the hired work, which is implemented without legalising the work relations, i.e. without a labour contract or creative contract between an employer and an employee, independently from the fact to which sector (private, state or individual) the employer belongs. An employee who is employed illegally is not granted the right to the social insurance, does not pay the income tax and the working time of such employee is not included into his work experience. An employer does not pay the social insure tax and benefit for such employees into the Work fund;

- working "privately" if the economic activity is implemented without realising financial obligations (e.g. taxes) for the state;

- work of a registered unemployed person, without announcing this to the appropriate institutions;
- work of an alien, who does not have a permission to work in a country (in such cases, when this permission is essential) or he is working in other conditions, if it is indicated in the permission.

As in other countries, in Poland there are classifications of the cases of illegal work. In this case, when time and income are analysed it is divided into:

1) the main, i.e. the one that usually takes up most of the time. If various jobs that are undertaken take up a time period that is almost the same, the main one is considered to be that work for which the biggest salary is received;

2) additional, i.e. the one which takes up most of the time, not including the main work. Additional work is considered such work (if there are more of them) from which most of the income is received (again, upon refusing the main one).

In Lithuania the concept of illegal work is defined in Article 98 of the Labour Code of the Republic of Lithuania, where it is established that illegal work is a work, which is performed for the benefit of an employer and upon his management or his supervision, when an employee, performing work functions obeys the established work organisation order and which meets at least one of these features i.e. the features of working agreement established in Article 93 of this Code and the work is done without concluding a written working agreement; an employee has not announced the Social State Insurance Fund Board one day prior the intended day for the beginning of the work; this work is performed by foreign citizens and stateless persons failing to comply with the procedure of their employment established by regulatory acts; the work is done by the citizens of the third countries, who are employed without meeting the requirements established in paragraphs 1,2 and 3 of part 1 
of Article 98 of the Code (Labour Code of the Republic of Lithuania; Bagdanskis \& Usonis, 2011).

Ministry of Social Security and Labour considers illegal work as any commercial, economic, financial or professional activity performed without setting up an enterprise in compliance with the procedure established by law or without buying a proper patent to engage in certain activities, when part of the salary is paid in illegally, when persons are employed in illegal enterprises without a labour contract and when they work for longer period than it is established in the official labour contract (http://www.socmin.lt/lt/darbo-rinka-uzimtumas/darboteise/nelegalus-darbas.html).

It may be stated that the definition of illegal work covers a variety of definitions/concepts, which in the case of the individual EU countries may be treated in a certain manner. It should be noted that even though some certain concepts of illegal work were defined by the regulatory/legal documents long time ago, the unified definition of illegal work is rather complex because of the overlapping concepts. The totality of the provided concepts and their mutual combinations allow highlighting the limits for defining the illegal work, and to juxtapose the diversity and complexity of the features defining illegal work. Williams, Nadin \& Windebank (2011) indicates that pursuing the eradication of such work is neither effective nor necessarily desirable since most governments wish to move such endeavour into the declared realm rather than simply eradicate it.

\section{The Identification of the Methodologies for Assessing the Illegal Work and the Differences of Scope}

In the opinion of Startiene \& Trimonis, (2009) undeclared work is one of the essential parts of shadow economy. Both of the might be defined in a variety of ways. Anecdotal evidence suggests that shadow economies in the Baltic States and other emerging Central and Eastern European countries are substantial in size relative to GDP. This is an important issue for these countries because informal production has a number of negative consequences (Putnins \& Sauka, 2011).

The assessments of both shadow economy and the extent of illegal work itself are complicated because of the lack of objective information. Furthermore, not only the extent but also the structure of shadow economy and undeclared work are different in the member states. In all of the democratic countries illegal work is usually apparent in sectors, where there is a high need of physical work, not requiring high qualification or competence: construction, agriculture, transport, trade, feeding sectors, household services, nursing and teaching/studies.

The differences in the extent of illegal work appear because of the unequal production structure and state welfare system (SOC/480). The exemplary initiatives are applicable in the Northern European countries, where more funding is given for the labour market, social security and income redistribution policy; therefore, there, the income of the residents is more equal as well as the effect of the undeclared work is smaller as well as this work is usually related with the second job, which is performed in order to increase the income. However, in the South Europe drawback of the active work market and welfare policy are compensated with the shadow economy and therefore unemployed persons and people for whom it is extremely difficult to get to the labour market are usually participating there (Eurofound, 2013).

Depending on the methodological access, and the chosen assessment methodology, different results are possible. As stated by Zukauskas (2014), the extent of the labour market as well as other activities of the shadow economy is difficult to access as this activity is hidden. In order to assess the extent and dynamics of the labour market shadow, various ways are used, which allow to at least approximately and quantitatively describe the labour market shadow.

Currently the comparative data of all of the European Union countries are received using the econometric modelling of the shadow economy or by performing the direct sample surveys of a certain part of employees working unofficially. In one of the studies performed in the European Union it was recommend to apply the indirect methodology crated by the Italian National Institute of Statistics, which is based on the information collected from the employees which is easily received and liable (Brodolini, 2009) for the assessment of illegal work. Applying one methodology would allow creating a comparative data base, independently from the research centres and contracted research. At the same time the variety of results would be avoided. Usually, the indicators announced in the national sources are lower than the research calculated by the experts and international organisations (SOC/480).

On the one hand, different methodological accesses for the assessment of the illegal work in the individual EU countries highlight the fields of analysis for illegal work, as a research object. On the other hand, the identification of the assessment methodologies, the differences of their application and the extent would help to base the theoretical methodological access/ instrument in order to perform complex research of illegal work in Lithuania. Currently, the comparative data of undeclared work in the EU Member States are received using:

- macroeconomic econometric modelling for shadow economy. Shadow economy, including undeclared work, is assessed based on the extents of the operations recorded by monetary funds and undeclared operations as well as by the amount of uncollected tax;

- when performing direct sample surveys of a particular part of employees working unofficially (hired employees and the ones that are self-employed). Results of the latter ones are in part controversial, since various aspects are analysed. However, only a small number of Member States are regularly performing the research of this phenomenon (Feld \& Larsen, 2005).

In Germany there is no accepted regulation on the application of the unified methodology for the assessment of the shadow economy; therefore, to this day several assessment methodologies are applicable for the shadow economy and at the same time the illegal work. Considering the macroeconomic assessments the tendency is observed of the reducing of the undeclared work. This 
may be influenced by a rather favourable environment for the legal work in Germany. Illegal migrants are granted the opportunity to acquire the certificates of permanent work, local resident are created the measures of "mini work" providing the fiscal incentives (Kriechel, 2012).

Currently Ireland also does not have a regulated methodology for assessing the illegal work, even though illegal work constitutes the biggest part of the growing shadow economy. In Ireland, the extents of the illegal work are established based on the statistics of the shadow economy. Since the illegal work is recorded as a percentage of a shadow economy, it is natural that when the shadow is increasing the illegal work increases at the same time. In theory this tendency could be justified, but the empirical data about the extent of the undeclared work would allow assessing the extent of the illegal work and its connections with the shadow economy in a more realistic way. Based on a rough estimate, the undeclared work accounts for 30 percent of all the shadow economy. Based on the data of 2011, the shadow economy in Ireland constitutes for 12.7 percent of GDP or 20 billion Euros. Data was received basing it on MMIC methods, which was adapted in Ireland by the professor F.Schneider. Application of this model is criticised because of a possibile overestimation of a shadow economy, but at the same time provides data, which could be compared with the statistics of other EU countries (Maedhbh \& Comm, 2013).

In the Northern European countries as well as in some other EU countries, undeclared work is usually measured by indirect indicators. When applying the discrepancy method - income and consumption are compared. This method is used the most as well as is considered the main indicator for measuring undeclared work in Sweden. The essence of the method is that it may be easier to hide income than consumption. Of course, declared income does not cover the income concealed for tax reasons, while consumption shows it, so the difference between the declared income and consumption shall be assessed as part of the shadow economy. Since neither direct nor indirect taxes exist in it, the biggest part of it could be assigned to the undeclared work. The essence of the method called the degree of participation is that in such cases when the participation in the official work is limited there would necessarily appear the rearrangement of employees to the undeclared work. This is used the most as well as is considered the main indicator for measuring undeclared work in Finland. It is noted that when applying this method in this country it is relied more on the qualitative analysis than the interviews from the experts. The drawback of the main method is that people working the undeclared work may also have an official work and part of the income received from the official work may also be undeclared. Furthermore, other methods are applied in both of the countries (Sweden and Finland):

1) Labour Input Method. Institutions, recording the supply in the labour market (e.g. Labour Exchange) may register part of the undeclared work, since people are less motivated to hide undeclared work than companies. When using this method, the above mentioned information is compared with the information from the point of view of labour force demand (employers) research, and this is compared in order to reveal the real extent of the undeclared work.

2) Tanzi Method is based on an assumption that the shadow transactions are performed only using cash. This method receives a lot of criticism, since the assumption that the undeclared work is affected only by the tax level is highly doubtful. This, as all the other monetary methods, emphasize that the change in the ratio of cash and deposits until the requirement, show the tendencies of the change in the undeclared work. The essential assumption of the model itself, stating that the transactions of the informal economy are performed only using cash causes certain doubts. And the change in the ratio of cash and deposits until the requirement is related more with the different activity of the banks than with the increase of the undeclared work.

3) Methods used in Sweden and Finland to ensure the triangulation principle

- Global indicators method - electricity consumption. Electric energy consumption is one of the best indicators of economic activity. In this case the elasticity of this indicator in regard to the GDP is almost equal to 1 . The difference in the increase of the electric energy consumption and the GDP increase may be assessed as approximate amount of undeclared work.

- Latent Variable Methods - MIMIC (multiple indicators and multiple causes) or DYMIMIC (dynamic multiple indicators and multiple causes). Its assumption: undeclared work is invisible (or latent) variable, which affects the observed indicators and establishes the size of the observed variables. When using this method, it is first of all sought the determining actions (e.g. real and imaginary tax burden, tax regulation, tax morality etc.) and indicators (involvement of the individuals into the labour market, hours that have been devoted to work and the real GDP). Then the undeclared work is calculated with the help of econometric measures such as MIMIC or DYMIMIC.

In the Lithuanian scientific literature, the undeclared work tends to be assessed in two methods acknowledged in Europe, which are rarely used separately (Pocius, 2006; Krumplyte \& Samulevicius, 2010):

- Method of a difference between the expenses and the income (which, unfortunately covers not only the whole sphere of the undeclared (illegal) work, but also includes various incomes generated in illegal and even criminal transactions);

- Using the method of discrepancy between the real and declared labour force. The latter method is also debatable as it is based on the discrepancy between the indicators describing the work force, assigning the difference for illegal work.

Without the unified methodology for assessing the illegal work in the EU countries, highlighting the research methods and fields is relevant in creating a methodological base for making further/deeper/wider research of illegal work in Lithuania and to compare the data of individual countries. Still one of the most relevant research remain the one by the Austrian scientist F. Schneider, where it is emphasized that illegal work is one of the most important component of shadow economy and the methodology, which was applied in various EU countries is used. 


\section{The Extent and Measures for Reducing Legal Work in the EU Countries and Lithuania}

When analysing how undeclared work is fought with in 31 European countries Dekker et al. (2010) established that in 8 countries $(26 \%)$ there was only one institution, whose functions are to fight with the undeclared work. This is performed by Labour Inspectorate in Bulgaria, Cyprus, Czech Republic, Greece, Hungary, Iceland, Latvia, Lithuania, Malta, Luxembourg, Poland, Portugal, Romania, Slovakia, Slovenia and Spain. Social security institutions also contribute to the fight with illegal work in Belgium, France, Switzerland and Lichtenstein, and the tax institutions in Austria, Denmark, Estonia, Germany,
Finland, Ireland, Holland, Norway, Sweden and the United Kingdom.

Following the order of the European Commission, "Eurobarometer" performed research on undeclared work in the EU countries during the months of April and May of 2013. Please take a look for countries with a particularly high proportion of respondents saying that they have collected undeclared paid work in the last 12 months include Latvia $(11 \%)$, the Netherlands $(11 \%)$ and Estonia $(11 \%)$, Denmark (9\%), Lithuania (8\%), and Sweden (8 $\%)$, Slovenia (8\%), Croatia (7\%). Member States with a particularly low proportion of respondents reporting their involvement in undeclared paid work in the past year are Germany, Portugal, Cyprus, Italy and Ireland (2\% in each) and Malta (1\%) (see Figure 1).

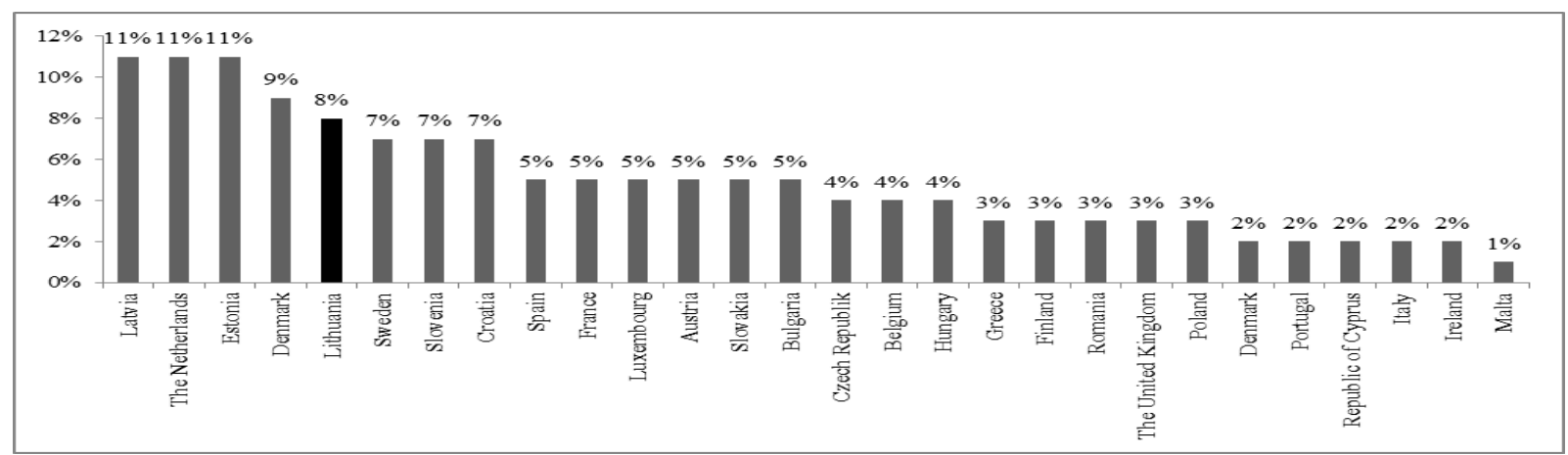

Figure 1. EU residents who confessed that they have received undeclared income together with the main salary for work Source: European Commission (2014). Special Eurobarometer 402 "Undeclared Work in the European Union"

Around 11 percent of Europeans confess that in 2012 they were buying products or services related to the undeclared work, while 4 percent acknowledged that they themselves received undeclared payment for the performed job. Furthermore, for one of 30 respondents ( 3 percent) part of the salary for work was paid in cash. Salaries avoiding the taxes constitute the biggest part of annual income in the South Europe (69 percent) as well as in the East and Middle Europe (29 percent) while in the continental and Northern countries this indicator is lower (appropriately 17 and 7 percent). Therefore, based on the data of the survey conducted by the "Eurobarometer" it may be stated that undeclared work in Europe is still widely spread, even though the extent of this problem is different in various countries.

In 2013 Employment and Social Developments in Europe (ESDE) review document these results were examined in more detail. As compared with the earlier survey of 2007, even if the general extent of the undeclared work is rather stable, different changes were observed in various countries:

- in some countries, for example, Latvia, the supply of undeclared work reduced significantly, while in Spain and Slovenia is increased a little;

- the demand of undeclared work significantly increased in Greece, Cyprus, Malta and Slovenia;

- during the crisis there were less cases when the salary for work was paid in cash directly to the employee, especially in the Middle and East Europe, but their number increased in Greece.
When examining the problems of the undeclared work in Lithuania, it was established that surveys were usually used to assess the extents of undeclared work. Zukauskas (2014) claims that when questioning the participants of the labour market and the experts it is possible to directly assess the extent of the labour market shadow, the reasons for the appearance of this shadow etc. On January 2014, by the order of the Lithuanian Free Market Institute, the representative survey of the residents was performed, which shown that in 2013 around 22 percent of the Lithuanian residents were working in a hiring work unofficially, or when working in such job they would receive part of their salary illegally (see Figure 2).

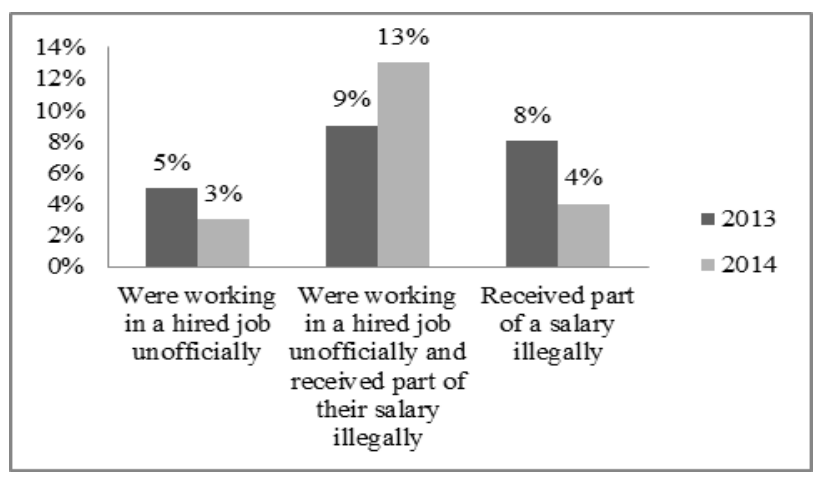

Figure 2. Labour market shadow in Lithuania

During this survey Lithuanian residents were asked about themselves or their family members (such practice is also used when performing research in other EU countries). It is still possible that part of the respondents 
did not want or did not dare to respond honestly; therefore, it is thought that in reality there are more people in Lithuania who work without concluding working agreements or those who receive part of their salary illegally.

Based on the data of various resident surveys (in 2006 - "Eurobarometer", in 2009-2013 - "Spinter" surveys) it is possible to provide the dynamics of illegal work in Lithuania (see Figure 3).

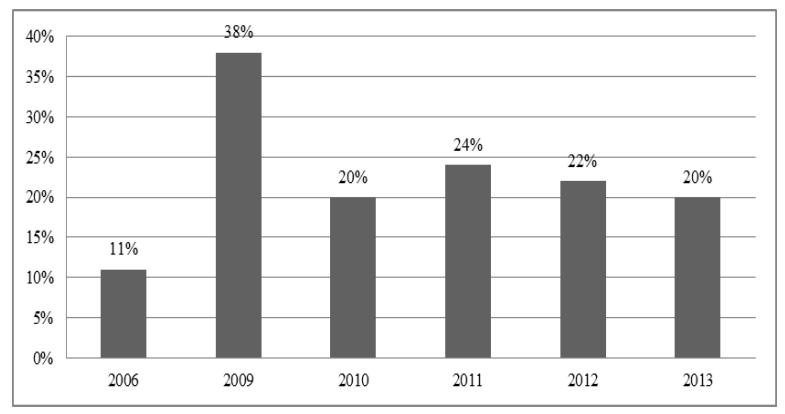

Figure 3. Dynamics of labour market shadow in Lithuania

The data analysis shows that illegal work in Lithuanian has strongly increased during the period of the economic crisis. Illegal work is an important problem for the shadow economy in Lithuania. As the reasons that have the biggest impact when choosing the relations of illegal work, it is possible to mention: high taxation of a labour force in Lithuania and strict regulation of the working relations. Therefore it is necessary to form clear political guidelines in the country in a fight with the shadow, by including various institutions, so that the impact of illegal work to the economy would be solved in a complex way. When fighting with illegal work it is suggested to involve the society itself as well as more of various institutions, by extending their operational functions, promoting cooperation and coherence of actions. It is relevant to initiate the simplification of the procedures and control the illegal work in the companies of "receptive" sectors, by orienting to the lower taxation of labour force and more flexible regulation of work relations.

When analysing the situation of fighting with illegal work in Lithuania, there is a lack of clear policy, even though there is a Central coordinating group for illegal work control, which consists of: State Labour Inspectorate under the Ministry of Social Security and Labour that coordinates the actions for control of illegal work phenomena implemented by the institutions; State Social Insurance Fund Board; State Tax Inspectorate under the Ministry of Finance; Financial Crime Investigation Service under the Ministry of the Interior; and Police Department under the Ministry of the Interior. Illegal labor controlling institutions in recent years, Lithuania has significantly intensified, more determined violators, but it does not eliminate causes of illegal employment. Because of this illegal activity is suffering not only the state budget, which receives considerable part of the revenue, but also the illegal workers, denying themselves the right to receive state social guarantees (Patapas \& Gudonis, 2014).

The effective cooperation between public and private institutions can be very well evaluated in Germany, Ireland and Scandinavian countries: when the bureaucracy is reduced and the partnership between the labour inspectorate and tax institutions help to generate the information quickly and to take up appropriate measures when fighting the illegal work. Also the employee qualification and innovative possibilities for creating innovative labour environment are highlighted. In order to reduce the extent of the shadow economy, involving the society into the process of reducing illegal work is considered to be one of the essential features, since educating the society about the negative effect of illegal work for the economy of the country influences the public spirit.

The experience of Ireland could be distinguished, when greater attention is paid for the macro economy of the country, considering the development of the infrastructure, environmental safety when applying the differentiated combination of socio-economic policy.

In a fight with illegal work the measures that were applied by Germany are very attractive, when the income support measures are related to the social contribution and benefits; when new work forms are regulated and the need of companies and employees are adjusted; when the activity is promoted for such Small Medium Business Enterprises, where qualified employees are working. Furthermore, reduction of bureaucratic borders when registering and implementing the activity in such companies would also encourage the creation and development of business.

Attention shall be drawn to the experience of the Scandinavian countries, when the taxes are returned in those sectors, which were mostly influenced by undeclared work and where it creates the added value. Both in Sweden and Finland, the elements of control mechanism for illegal work are similar and direct to the reduction of procedures, flexibility and increase in the preventive measures.

Experience of Poland is important for Lithuania not only because of close neighbourhood, cultural similarities and historical aspect, but first of all because of a stable economic and secondly because of the successful reforms that are preformed most rapidly. Based on data of Polish labour inspectorate, the number of alien working in the country illegally has decreased from 2012 by one fourth. The improving economic - social environment in a country and especially the accepted new political measures should contribute to the return of immigrants and repatriation, since almost twenty million people live abroad, including two million Polish people, who immigrated to the West Europe after entering the European Union (Ministry of Foreign Affairs of Poland 2013).

It should be noted that the good experience of the countries in a fight with illegal work is directed in order to reduce its demand and not to increase its preventive or punitive measures. Purpose - for many decades, European national governments sought to stamp out undeclared work using a repressive approach. In the changing economic context of declining employment participation rates, however, the EU has called for a new approach to transform undeclared work into declared work. This necessitates public policy innovations. If undeclared jobs are to be transformed into declared jobs and economic inclusion promoted, national governments will need to accord more priority to innovative new policy measures to legitimise declared work than is currently the case (Williams, Windebank, Baric \& Nadin, 2013). 


\section{Conclusions}

By analysing the practice of the individual European Union countries, the diversity of the illegal work treatment and political-economic means has been identified. It depends on the country's institutions that inspect illegal work. The illegal work definition covers a wide range of concepts, approached differently throughout the European Union countries. However, irrespective of the legislation of a country, illegal work is a part of the shadow economy. Generally, it can be treated as any illegal work activity that violates the applicable law and involves other illegal work forms, aspects and interpretations. Usually it is unregistered, undeclared work, shadow, "black" work, informal recruitment, etc. It should be noted that, nevertheless some concepts of illegal work have been acknowledged by the legislation and the regulatory acts of the European Union countries for some time, the unification of the illegal work definition remains unclear due to the overlapping concepts. The given concepts and their interrelations let us emphasize the limits of the illegal work definition and form a certain opinion about the versatility and complexity of the illegal work features. In summary, we could say that the illegal work definitions highlight taxes, salaries, employment contracts, activity and work duration as well as its accounting, supply of socially-oriented products and services and illegal immigrant work.

The scientific literature analysis shows that the changes and situation concerning the labour market (illegal as well) are evaluated by analysing different methodological access and uneven criteria. That's why the labour market reforms are implemented differently in the individual European Union countries. It is related not only to the economic and social state, demographic changes and legal base of the countries, but also to the different policy, approach and evaluation indicators. It is difficult to evaluate the illegal work scale in the European Union countries, because those operating in the shadows tend to conceal their activity. Also, there is a lack of unified evaluation methods, which allow performing the comparative analysis between the countries with different production structure and state welfare system. Currently, the illegal work evaluation in the European Union countries is implemented by using various methods that allow the approximate quantitative evaluation of the illegal work scale. Usually they are based on the shadow economy's macroeconomic econometric modelling, when the shadow economy, including undeclared work, is evaluated considering the scale of the fund accounted and undeclared operations as well as the amount of uncollected taxes. Also, the direct surveys, implemented in order to determine the percentage of unofficially employed workers (freelancers and self-employed), show controversial results. On the one hand, different methodological approaches of the illegal work evaluation in the individual European Union countries emphasize the fields of the illegal work (as a research subject) analysis. On the other hand, there is no unified methodological approach concerning the illegal work evaluation in the European Union countries, so the emphasis on the research methods and fields remains relevant, while creating the methodological base for the further/deeper/broader illegal work researches in Lithuania. Moreover, there is no potentiality to implement the data comparison and analysis of the illegal work scale between the countries. Therefore, it would be reasonable to consider the research data of a scientist Friedrich Schneider, which highlights that illegal work is one of the most important shadow economy components. The methodology used by the author is applied in various European Union countries.

The data analysis shows that illegal work in Lithuania has increased during the years of the economic crisis and is a relevant problem in the fight against the shadow economy in the country. The main reasons for choosing the illegal work relations are high labour taxation and strict work relations control. The researches and surveys implemented in various countries revealed the fluctuation of the illegal work fields and its scale. That's why in the fight against illegal work it is essential not only to promote the economic factors, which create favourable conditions for the illegal work reduction and its evaluation methodology unification, but also to exchange the information between the countries. The best practice spread can be beneficial to the state, and by creating the respective means, to the institutions and the workers, operating in the state. It is suggested that the whole society and more various institutions should be included, by expanding the functions of their activities, promoting cooperation and the compatibility of their actions. It is relevant to initiate the procedure and inspection simplification regarding illegal work in the susceptible sector companies by promoting the lower labour taxation and more flexible work relations control. Highly favourable is the effective co-operation of the public and private institutions in Germany, Ireland and Scandinavia. The bureaucracy in these countries is being reduced, and the partnership between the work inspection and the tax authorities helps to generate the information quickly and take actions in the fight against illegal work. Germany takes the lead in the fight against illegal work, when the means of the income promotion are related to social deposits and benefits; when the new work forms are regulated and the needs of the institutions and the workers are coordinated. Both in Sweden and in Finland the elements of the illegal work control are similar and directed to the procedure reduction, flexibility and the promotion of the preventive measures. It should be noted that the best practice in the fight against illegal work is its demand reduction and not the promotion of the preventive or punitive measures. Moreover, it is reasonable for the European Union countries to support a single policy and continue the illegal work observation, especially by foreseeing the preventive measures in the country's labour market and creating the directions for the new policy regarding the migration processes. 
Rima Zitkiene, Zaneta Karazijiene, Egle Kazlauskiene. Problems in Assessing the Expression of Illegal Work from ...

\section{References}

Arezzo, M. (2014). Social Capital and Undeclared Work: An Empirical Analysis in Italy from 1998 to 2008. Social Indicators Research, 118(2), 695-709. doi:10.1007/s11205-013-0434-4.

Bagdanskis, T., \& Usonis, J. (2011). Problems of Qualifying an Employment Relationship and Undeclared Work in Lithuania. JURISPRUDENCE, 18(3), 1101-1122.

Berzinskiene, D., \& Juozaitiene, L. (2011). Impact of Labour Market Measures on Unemloyment. Inzinerine EkonomikaEngineering Economics, 22(2), 186-195.

Brodolini, F. G. (2009). Study on indirect measurement methods for undeclared work in the EU (VC/2008/0305) European Commission, Directorate-General Employment, Social Affairs and Equal Opportunities Unit EMPL/D1 Employment Analysis.

Commission of the European Communities. (2007). Communication from the commission to the council, the European Parliament, the European Economic and Social Committee and the Committee of the Regions. Stepping up the fight against undeclared work. (COM 628). Available from internet: http://eur-lex.europa.eu/legalcontent/EN/ALL/:ELX_SESSIONID=cCPhJPBcrGcSrPB1ysr1dFftpGRN8NXvPY1VGMKhZyXLsd1fcg76! 873639365? uri=CELEX:52007DC0628

Cichocki, S., \& Tyrowicz, J. (2010) Zrodla zatrudnienia niejejestrowanego w Polsce. Bank i Kredyt 41(1), 81-98. Available from internet: www.bankiikredyt.nbp.pl

Dagiliene, L., Leitoniene, S., \& Grencikova, A. (2014). Increasing Business Transparency by Corporate Social Reporting: Development and Problems in Lithuania. Inzinerine Ekonomika-Engineering Economics, 25(1), 54-61. http://dx.doi.org/10.5755/j01.ee.25.1.2356

Dekker, H., Oranje, E., Renooy, P., Rosing, F., \&Williams, C. C. (2010). Joining up the fight against undeclared working the European Union, DG Employment, Social Affairs and Equal Opportunities, Brussels. Available from internet: http://ec.europa.eu/social/main.jsp?catId=471\&langId=en.

Di Porto, E. (2009). Audit, Tax Compliance and Undeclared Work: An Empirical Analysis [accessed 10 December 2009$].$ Available from Internet: 〈http://www.laboratoriorevelli.it/_pdf/ wp94.pdf>

Diamantopoulou, A. (2002). Anna Diamantopoulou welcomes Latvia's agreement to shadow EU employment strategy in run-up to full accession. Available from internet: www.mwia.net/update21.pdf. IP-03-188

Eurofound. (2013). Tackling undeclared work in 27 European Union Member States and Norway: Approaches and measures since 2008, Eurofound, Dublin.

Hazans, M. (2011). Informal Workers across Europe. Evidence from 30 European Countries. Policy research working paper: 5912. World Bank. Available from internet: http://elibrary.worldbank.org/doi/book/10.1596/1813-94505912

Henley, A., Arabsheibani, G. R., \& Carneiro, F. G. (2006). On Defining and Measuring the Informal Sector. World Bank Policy Research Working Paper 3866. Available from internet: http://elibrary.worldbank.org/doi/pdf /10.1596/1813-9450-3866

Egerton, M., \& Mullan, K. (2008). Being a pretty good citizen: an analysis and monetary valuation of formal and informal

voluntary work by gender and educational attainment. The British Journal of Sociology, 59(1), $145-164$. doi:10.1111/j.1468-4446.2007.00186.x

European Commission. (2014). Special Eurobarometer 402 "Undeclared Work in the European Union". Available from internet: (http://ec.europa.eu/public_opinion/archives/eb_special_419_400_en.htm - 402)

European Comissions. (2013). Employment and Social Developments in Europe 2013 (ESDE). Available from internet: http://ec.europa.eu/social/main.jsp?catId=738\&langId=lt\&pubId=7684.

Feld, L. P., \& Larsen, C. (2005). Black Activities in Germany in 2001 and in 2004. A Comparison Based on Survey Data. Available from internet: http://www.rockwoolfonden.dk/files/RFF-site/Publikations\%20upload/Study\%20 Papers\%20-\%20uk\%20site/Black\%20Activities\%20in\%20Germany\%20in\%202001\%20and\%20in \%202004. study_12.pdf

Jonsson, H. (2002). Undeclared Work in Sweden - Results and Recommendations. Available from internet: www.academyavignon.net/undwork.htm.

Jorg, Fr., A. SJ. (1999). Illegal in Germany. Summary of results of the research project on the life situation of 'illegal' migrants in Leipzig. Available from internet: http://www.joerg-alt.de/English/Summary.pdf

Kriechel, B. (2012). Undeclared Work in Germany. Peer Review on "Tackling undeclared work: developing an effective system for inspection and prevention”. Mutual Learning Programme 2012 Autumn Peer Reviews. Available from internet: http://ec.europa.eu/social/main.jsp?catId=1070\&langId=en\&newsId=1947\&moreDocuments=yes\& table Name $=$ news 
Krumplyte, J., \& Samulevicius, J. (2010). Complex Research on Undeclared Work: Theoretical Aspects and Empirical Application in Lithuania. Inzinerine Ekonomika-Engineering Economics, 21(3), 283-294

Krumplyte, J. (2009). Seselines ekonomikos veiksniu ir priezasciu tyrimas ekspertinio vertinimo metodu: Lietuvos atvejis. Verslas, vadyba ir studijos, VGTU. 122-138.

Larsen, L. B. (2013). Buy or barter? Illegal yet licit purchases of work in contemporary Sweden. Focaal-Journal of Global and Historical Anthropology 66: 75-87. doi:10.3167/fcl.2013.660108.

Lietuvos Respublikos darbo kodeksas. (2002). Zinios Nr. 64-2569. Available from internet: http://www3.lrs.lt/pls/inter3/ dokpaieska.showdoc_1?p_id=437930

Lietuvos Respublikos socialines apsaugos ir darbo ministerija. Nelegalus darbas. Available from internet: http://www.socmin.lt/lt/darbo-rinka-uzimtumas/darbo-teise/nelegalus-darbas.html

Martinkus, B., Sakalas, A., \& Savaneviciene, A. (2006). Darbo istekliu ekonomika ir valdymas (pp. 86). Kaunas: Technologija.

Maedhbh, C., \& Comm, B. (2013). The role of the Irish National Labour Inspection System (National Employment Rights Authority -NERA) as part of a strategic policy response to undeclared work/ ILO/EC Comparative Study on Labour Inspection Strategies for Combating Undeclared Work in Europe. Available from internet: http://www.ilo.org/wcmsp5/groups/public/-ed_dialogue/-lab_admin/documents/genericdocument/wcms_224583.pdf

Meldolesi, L. (2003). Policy for the Regulation of the Underground Economy and Employment, Review of Economic Conditions in Italy. No I, January-April. Available from internet: www.emersionelavorononregolare.it/ catania/ index.php.

Misiunas, A. (1999). Seselines ekonomikos egzistavimo priezastys ir padariniai, Pinigu studijos 1, 21-29.

Nielegalna praca w świetle obowiązujących przepisów, uprawnienia Państwowej Inspekcji Pracy i innych organów w zakresie kontroli nielegalnego zatrudnienia. (2013). Available from internet: http://www.pup.cieszyn.pl/data/ files/file/nielegalne\%20zatrudnienie.pdf

Pasternak - Malicka M. (2013) Zatrudniene nierejestrowane w kontekscie problematyki bezrobocia w Polsce. Studia BAS $\mathrm{Nr}$ 4(36) p. 27-56. Available from internet: www.bas.sejm.gov.pl

Patapas, A., \& Gudonis, N. (2014). Undeclared Work Control Efficiency Problem in Lithuania. PUBLIC POLICY AND ADMINISTRATION, 13(4), 659-670. doi:10.13165/VPA-14-13-4-09.

Pedersen, S. (2003). The Shadow Economy in Germany, Great Britain and Scandinavia: A Measurement based on Questionnaire Surveys, Rockwool Foundation Research. Copenhagen: Unit Study No. 10.

Perry, G. E., Maloney, W. F., Arias, O. S., Fajnzylber, P., Mason, A. D., \& Saavedra-Chanduvi, J. (2007). Informality: Exit and Exclusion. Washington D.C.: The World Bank. Available from internet: https://openknowledge.worldbank.org/ bitstream/handle/10986/6730/400080Informal101OFFICIAL0USE0ONLY1.pdf?sequence=1

Pocius, A., \& Okuneviciute-Neverdauskiene, L. (2007). Neoficialaus uzimtumo Lietuvoje ivertinimas. Lietuvos statistikos darbai (45), 6-15.

Pocius, A. (2006). Neoficialaus uzimtumo bukles ir dinamikos skaiciavimai - Estimating the Situation and Dynamics of Informal Employment. Lietuvos ekonomikos apzvalga - The Review of Lithuanian Economy (2), 95-101.

Praca Nierejestrowana w Polsce w 2010 r. (2011). Statistical Information and Elaborations. Available from internet: http://stat.gov.pl/cps/rde/xbcr/gus/pw_praca_nierejestrowana_w_2010.pdf

Praca na czarno: kuedy ryzykuje pracownik. (2014) Available from internet: http://praca.wp.pl/prawo-pracy.html

Raisanen H., Alatalo J., Henriksen K.K., Israelsson T., Klinger S.(2012) Labour Market Reforms and Permormance in Denmark, Germany, Sweden and Finland. Publication of the Ministry of Employment and the Economy Employment and entrepreneurship. Available from internet: http://www.tem.fi/files/ 32993/TEMjul_ 19_2012.web.pdf

Schneider, F. (2001). Increasing Shadow Economies in OECD Countries: Some Further Explanations. Brussels, revised version in March. Available from internet: www.econ.jku.at/Schneider/Encyclopedia.pdf.

Schneider, F. (2001). Regulation and the underground economy. The Liberty Briefing. Europe, No. 1. Available from internet: http://assets.cambridge.org/052181/408/frontmatter/0521814081_frontmatter.pdf.

Schneider, F. (2012). The Shadow Economy and Work in the Shadow: What Do We (Not) Know?IIZA Discussion Paper No 6423. Available from internet:http://ftp.iza.org/dp6423.pdf

Schneider, F. (2014). Work in the Shadow: Micro and Macro Results. International Economic Journal. 28 (3), $365-379$. doi:10.1080/10168737.2014.936924.

Startiene, G., \& Trimonis, K. (2009). The Size of Non-Observed Economy. Ekonomika ir vadyba-Economics and Management 14, 976-983.

Palmieri S. Europos ekonomikos ir socialiniu reikalu komitetas. (2013). Uzimtumo, socialiniu reikalu ir pilietybes skyriaus nuomone del Kovos su seseline ekonomika ir nedeklaruojamu darbu strategija (SOC/480). 
Rima Zitkiene, Zaneta Karazijiene, Egle Kazlauskiene. Problems in Assessing the Expression of Illegal Work from ...

Pfau-Effinger, B. (2009). Varieties of UndeclaredWork in European Societies. British Journal of Industrial Relations, 47:1 March 0007-1080 pp. 79-99. doi:10.1111/j.1467-8543.2008.00711.x.

Putnins, T. J., \& Sauka, A. (2011). Size and determinants of shadow economies in the Baltic States. Baltic Journal of Economics 11(2) 5-25.

Valstybine darbo inspekcija. (2013). Informacija apie valstybines darbo inspekcijos prie socialines apsaugos ir darbo ministerijos vykdoma nelegalaus darbo reiskiniu kontroles koordinavima bei priemones vykdant nelegalaus darbo prevencija per 2013 metus. Available from internet: http://www.vdi.lt/PdfUploads/ND2013ataskaita.pdf

Varela Llamas, R. (2014). Income Dif ferences on Mexico's Northern Border: A Perspective on Formal and Informal Employment. FRONTERA NORTE, 27(53), 177-203.

Vos, S., Breesch, D., \& Scheerder, J. (2012). Undeclared Work in Non-Profit Sports Clubs: A Mixed Method Approach for Assessing the Size and Motives. International Society for Third-Sector Research, 23, 846-869. doi:10.1007/s11266-011-9232-2

Williams, C. C. (2009). From the Formal/Informal Work Dichotomy to Hybrid Semiformal Work Practices. International Journal of Sociology, 39(2), 39-59. doi:10.2753/IJS0020-7659390202.

Williams, C. C. (2010). Tackling undeclared work in southeast Europe: lessons from a 2007 Eurobarometer survey. Southeast European and Black Sea Studies, 10(2), 123-145. doi:10.1080/14683857.2010.486944.

Williams, C. C. (2011). Reconceptualizing Women's and Men's Undeclared Work: Some Results from a European Union

Survey. Gender, Work and Organization, 18(4). doi:10.1111/j.1468-0432.2009.00466.x.

Williams, C. C., Windebank, J., Baric, M., \& Nadin, S. (2013). Public policy innovations: the case of undeclared work. Management Decision, 51(6), 1161-1175. doi: 10.1108/MD-10-2011-0341.

Williams, C. C., Nadin, S. J. \& Windebank, J. (2011). Undeclared work in the European construction industry: evidence from a 2007 Eurobarometer survey. Construction Management and Economics, 29, 853-867. http://dx.doi.org/10.1080/01446193.2011.610331

Zukauskas, V. (2014). Lietuvos seseline ekonomika. Periodinis leidinys, Nr. 3. Lietuvos laisvosios rinkos institutas. Available from internet: http://files.lrinka.lt/Seseline_ekonomika/LSE3.pdf

The article has been reviewed.

Received in December 2014; accepted in February, 2016. 